\title{
Correction to: Natural products in drug discovery and human health
}

\author{
Maria-José U. Ferreira
}

Published online: 4 March 2021

(C) Springer Nature B.V. 2021 species namely Calendula species, Pterospartum tridentatum (L.) Willk. and several halophytes growing in Portugal" should read as "Aiming at valorizing Portuguese plants as source of bioactive compounds, Pinto and Silva (2020) reviewed their contribution to establish the chemical profile and to validate some of the health benefits claimed for some species namely Calendula species, Pterospartum tridentatum (L.) Willk. and several halophytes growing in Portugal. They also focused on economically important species, which are at risk of being damaged by climate changes, such as Olea europaea L. and Eucalyptus globulus Labill., aiming at evaluating the impact that climate-change-related conditions can have in their metabolome profile".

The original article has been corrected.

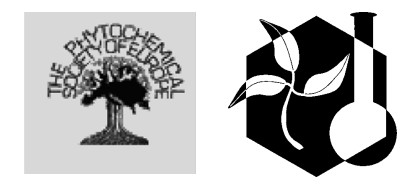

Publisher's Note Springer Nature remains neutral with regard to jurisdictional claims in published maps and institutional affiliations.
The original article can be found online at https:// doi.org/10.1007/s11101-020-09736-y.

\section{M.-J. U. Ferreira ( $\square)$}

Research Institute for Medicines (iMed.ULisboa), Faculty of Pharmacy, Universidade de Lisboa, Av. Prof. Gama

Pinto, 1649-003 Lisbon, Portugal

e-mail: mjuferreira@ff.ulisboa.pt 